\title{
It is just not fair: the Endangered Species Act in the United States and Ontario
}

\author{
Andrea Olive $^{1}$
}

\begin{abstract}
The United States and the Canadian province of Ontario have enacted endangered species laws that regulate private land. The rationale for this is that the vast majority of endangered species in the two countries rely on private lands for survival. However, from a landowner perspective the law is deemed unfair. This paper presents analysis from 141 interviews with landowners in three U.S. states and Ontario. In recognition of distributive justice claims, both the U.S. government and the Ontario government have enacted programs aimed at increasing financial incentives for participation and compliance with the law. However, the law is still perceived as unfair. The central argument of this paper is that future amendments and new policies for endangered species should confront two other forms of environmental justice: procedural justice and justice-as-recognition. Landowners in both countries expressed not only concerns about compensation, but also a deep desire to be included in the protection and recovery process, as well as to be recognized by government and society as good stewards of the land. The paper concludes by stating that future policy amendments need to address justice-as-recognition if endangered species conservation on private lands is to be considered fair by landowners.
\end{abstract}

Key Words: conservation; Endangered Species Act; environmental justice; justice-as-recognition; landowners; private property; procedural justice

\section{INTRODUCTION}

It is now well documented that the vast majority of endangered species in the United States and Canada rely on private lands for survival (Bean 1998, Dempsey et al. 2002, Knight 2006). Thus, it is no surprise the American Endangered Species Act (ESA) regulates private land for the purposes of protection and recovery of endangered species. In Canada, the Constitution divides responsibility for species at risk between the federal government and the provinces. The national Species at Risk Act protects endangered species found on federal lands (about $5 \%$ of land outside the North) as well as all migratory birds and most aquatic species. Among the provinces, Ontario has the most stringent ESA and it looks quite similar to the U.S. ESA on paper (Olive 2014). In fact, it is the only Canadian ESA to regulate private property in a similar fashion as the United States. Ontario is also Canada's most populated province. and its southern tip contains the densest biodiversity in the country (Knight 2006, Ontario Biodiversity Council 2010). This paper analyzes private land regulation in the context of the U.S. and Ontario ESAs from the perspective of landowners. The central question hinges on whether or not private land regulation for the purposes of conservation is unfair to landowners and, if so, what can be done about it.

Both ESAs prohibit the outright killing of a listed endangered species by anyone. In addition, both laws protect a listed species' habitat, making it an offense to impact a species' shelter, breeding patterns, or feeding (see Olive 2014 for a comparison of the laws). In practice this often means that a landowner is prevented from carrying out otherwise lawful activities like farming or even constructing a shed, adding a driveway, or removing rocks on their own property if it is listed as habitat for an endangered species on the ESA. However, although the law regulates private property in such a manner, that regulation is difficult to implement and monitor. There are thousands and thousands of land parcels to which the ESAs apply regulatory measures. The governments cannot watch all landowners at all times. The implication of this is that both laws rely on landowners to voluntarily obey the law and steward land for endangered species.

Social science literature suggests that citizens are more willing to comply with laws they consider fair (Tyler 1990, Levi 1997, Clayton 2000, Fehr and Falk 2002, May 2004, Wright et al. 2012, Olive 2014). There is a substantial literature around environmental justice that highlights the link between what individuals perceive as just and what individuals are willing to obey or voluntarily perform for environmental purposes. Empirical research has found that "beliefs about environmental (in)justice predict pro-environmental behavior" (Reese and Jacob 2015:88; see also Clayton 2000) and, along the same lines, "environmental behavior of stakeholders is likely to depend on how they perceive the legitimacy and fairness of ecosystem governance" (Sikor et al. 2014:525; see also Pascual et al. 2010, Muradina et al. 2013). Thus, if a person considers a law fair, then he or she is more likely to obey. Indeed, "justice reflects an important variable for understanding conditions that increase or decrease individuals' willingness to act in favor of the environment and supporting politics" (Reese and Jacob 2015:88; see also Kals and Russell 2001). The implication of this is that if the ESA is not considered fair by landowners, then they will not obey it and/ or they may not act in ways that enhance stewardship on private lands.

What does "justice" or "fairness" amount to in environmental cases? The concept of fairness is malleable and frequently ambiguous. This is mainly because "principles of equity are complex and contingent on circumstances, varied, and nuanced" (Ingram et al. 2008:8). What is considered fair in one context might be wildly unfair in another context (Stone 1990). That said, there are three broad categories of fairness or justice within the environmental realm: distributive justice, procedural justice, and justice-as-recognition (Schlosber 2004, Walker 2012, Sikor et al. 2014, Cantzler and Huynh 2016). 
Distributive justice is often thought of in economic terms or as resources received (Cropanzano and Ambrose 2001). This form of justice acknowledges that a burden exists and compensates those people in society who must bear the burden. This can be seen in paying, or otherwise compensating, landowners to conserve species on their land (Pascual et al. 2010, Muradian et al. 2013), install a wind turbine on their land (Aitken 2010, Cowell et al. 2012), or live close to a waste facility (Fletcher 2003). However, empirical studies have shown that compensating individuals or an entire community is not always successful at increasing policy acceptance or increasing policy compliance (Aitken 2010, Cowell et al. 2012). This may be because the government failed to get the incentive right (Stern 2006) or because the incentive fails to address the perceived unfairness.

Allowing and even enabling those individuals potentially impacted by a policy to participate in the process of making a policy is another form of justice. An open and transparent decision-making body can address issues of fairness and help to increase the social acceptability of a policy (Ottinger et al. 2014). As Levi (1997:3) argues, "In most cases citizens are willing to go along with a policy they do not prefer as long as it is made according to a process they deem legitimate." Conversely, a closed decision process can cause landowner or community alienation, and lead to frustration and risk of increasing noncompliance (May 2004, Olive 2014). There is evidence from a variety of environmental literatures ranging from wind and waste facility settings to greenhouse gas reductions that suggests that procedural justice is an integral part of successful policy design and implementation (see for examples Cropanzano and Ambrose 2001, Fletcher 2003, Aitken 2010, Sikor et al. 2014).

Procedural justice raises the important question of who should be included in decision making. The critical question is "Who or what is morally relevant?" (Muller and Clayton 2013:228). Scholarship in this field extends justice beyond the typical stakeholder framework to include future generations, i.e., intergenerational justice; economically disadvantaged nations, i.e., global justice; and nonhuman life and nature, i.e., ecological justice (see Sikor et al. 2014, Reese and Jacob 2015). These "participants" cannot be directly involved in decision making for environmental policy, but environmental justice requires that the values and interests of future generations, global citizens, and nature be genuinely considered and included in democratic policy making. For the purposes of conservation, other nonhuman living things may have rights that politics should respect, if not protect (Muller and Clayton 2013). How society includes these other stakeholders is deeply tied to procedural environmental justice.

Lastly, justice-as-recognition is concerned with acknowledging individual rights and values as well as culture and knowledge systems. It is premised on the idea that certain people are devalued by society (Walker 2012). One clear form of recognition is accommodation for spiritual or sacred sites (Martin et al. 2013, Sikor 2013). However, acknowledging culture or lifestyle can be another form of recognition. Research in Indigenous studies demonstrates the importance of cultural recognition in regard to feelings of subjection or domination in the policy process and in policy outcomes (Turner et al. 2008, Schlosberg and Carruthers 2010). Outside of Indigenous case studies, less attention has been paid to this form of environmental justice. Although some investigations into incentive and compensation schemes for landowners in the context of the endangered species conservation have acknowledged the importance of the rancher or famer lifestyle (Petersen and Choat Horton 1995, Sorice et al. 2012), very little attention has been given to how policy can be amended to address justice-as-recognition (see Doremus 2003). Recently scholars have started to examine the fairness of ecosystem service payments in relation to procedural justice and justice-as-recognition (Pascual et al. 2014). In this literature there is a more urgent call for understanding how these different forms of environmental justice are related and how they influence individual behavior. This present paper seeks to connect the literature on endangered species policy to environmental justice literature broadly, but specifically to considerations of justice-asrecognition research.

\section{Environmental justice and the ESAs}

Because justice appraisals are linked to compliance with public policy, what landowners think about the fairness of the ESA matters a great deal, especially because the government cannot be in everyone's backyard to enforce compliance. The problem is that empirical studies indicate that many landowners think ESA policy is unfair to them as landowners and citizens, at least from a distributive justice standpoint. Kreuter et al. (2006), for example, found that landowners in Colorado, Texas, and Utah generally disagreed with the notion that landowners should protect endangered species habitat without compensation from the public. Similarly, Brook et al. (2003:1641) found a positive correlation between landowners who thought they should not "bear financial responsibility" for conservation and those indicating that they managed their properties to minimize the chance of an endangered species occupying it. These studies have led to the conclusion that compensation would be fairer. A number of incentive mechanisms (money, subsidies, mitigation banking, tradable credits, tax reform) have been explored in the literature (see Farrier 1995, Doremus 2003, Parkhurst and Shogren 2003, Sorice et al. 2012).

The fact that the ESA might be unfair to American landowners did not play into congressional debates during the initially passage of the law (Olive and Raymond 2010). However, fairness has become quite central to the politics of the ESA (Farrier 1995, Olive 2014). The main focus has been on distributive justice, and recent amendments to the ESA have centered on ways to provide more compensation and incentives to landowners in cases where conservation will negatively impact their economic self-interest. The programs or amendments to the ESA that address distributive justice include incidental take permits, habitat conservation plans, safe harbor agreements, recovery credits and tax deductions, and conservation banking (U.S. Fish and Wildlife Service 2015).

The Ontario ESA was passed in 2007 and although no member of the Legislative Assembly invoked any lessons learned about distributive justice from U.S. ESA experience, there was much discussion of the "unfairness" of the proposed Ontario ESA. During parliamentary debate, one member of Provincial Parliament pointed out that the bill "promises enforcement measures without ensuring that proper and fair compensation for landowners is also built into the bill itself" (Miller 2007). It was his position, shared by a few other members of Provincial 
Table 1. Description of case studies.

\begin{tabular}{|c|c|c|c|}
\hline Location of interviews & $\begin{array}{c}\text { Number of interviews (out of } \\
\text { sample population) }\end{array}$ & Date of interviews & Endangered species of interest \\
\hline Conservation Management Area, Indiana & $22 / 40$ & Fall 2005 & Indiana Brown Bat (Myotis sodalis) \\
\hline Middle Bass Island, Ohio & $44 / 50$ & Summer 2007 & $\begin{array}{l}\text { Lake Erie Water Snake (Nerodia } \\
\text { sipedon insularum) }\end{array}$ \\
\hline Hurricane, Utah & $35 / 50$ & Summer 2007 & Desert Tortoise (Gopherus agassizii) \\
\hline Peel Island, Ontario & 18 & Summer 2010 & Lake Erie Water Snake \\
\hline Southern Ontario & 22 & Winter 2015 & N/A \\
\hline
\end{tabular}

Parliament, that "individual landowners should not be expected to pay entirely for the costs of a policy that benefits all society" (Miller 2007). The Ontario bill passed with some concessions made toward landowner compensation but nothing to address other justice issues.

The Ontario ESA does confront distributive justice aspects in similar ways as the U.S. ESA: through programs that provide financial incentives to landowners. These programs include a variety of tax incentive programs (see Ontario Ministry of Natural Resources and Forestry 2015). However, in both Ontario and the United States, landowners still consider the law to be fundamentally unfair. The central argument of this paper is that procedural justice and justice-as-recognition cannot be ignored. Landowners want all three forms of justice, but by and large the governments have focused on distributive justice.

\section{METHODS}

This paper draws on an analysis of 141 interviews conducted in three U.S. states and two Canadian provinces over the past ten years. The purpose of this paper is to draw together the case studies and examine the issue of environmental justice specifically, because prior research from these case studies has focused exclusively on private property and stewardship norms (see Olive 2014).

\section{Participants}

The U.S. case studies were with landowners in Indiana, Ohio, and Utah, and the Canadian cases were with landowners in different parts of Ontario. See Table 1 for a summary of the case studies. Landowners in all case studies represent nonagricultural landowners who own small parcels of property that are either directly listed as habitat for an endangered species or are in very close proximity to an endangered species. The focus is on nonagricultural landowners because they are an understudied population and because the law does directly impact their land and their land management decisions in ways that are not entirely understood in the literature (Raymond and Olive 2008, Milburn et al. 2010, Olive 2014, Kittredge et al. 2015).

In Indiana, I sampled landowners in the government-designated Conservation Management Area (CMA) for the Indiana Brown Bat (Myotis sodalis; see Raymond and Olive 2008). There were 40 landowners who owned property in the CMA and 22 agreed to an interview, which is a response rate of $54 \%$. In Ohio, I sampled landowners who own shoreline property on Middle Bass Island in Lake Erie because that is listed as critical habitat for the Lake Erie Water Snake (Nerodia sipedon insularum). There were a total of 317 land parcels, of which I randomly sampled 50 to be included in the study. I conducted 30 interviews with 40 people (in 5 cases I interviewed a married couple) and completed 3 interviews via a mailed copy of the survey (at the landowner's request) for a total response rate of $66 \%$, i.e., 33 parcels out of 50 parcels. In Utah, I sampled landowners living in a conservation zone for the Desert Tortoise (Gopherus agassizii). The entirety of Washington County in Southern Utah is part of a Habitat Conservation Plan with thousands of landowners living in the area. The Habitat Conservation Plan designates 10 zones of habitat that are of particular importance to tortoise protection because of the type and location of the land. Of these 10 zones, 4 contain private, nonagricultural landowners. I sampled from zone 7, the Hurricane Take Area, because this smaller zone is surrounded on three sides by the official tortoise reserve. There were 457 land parcels in this zone, and I randomly selected 50 parcels for inclusion in my study. In Utah, 15 landowners agreed to be interviewed in person, 15 completed a mail survey, and 4 interviews were conducted by phone. Thus, of the 50 total parcels, I interviewed 34 parcel owners for a response rate of $68 \%$.

The Ontario case studies were more difficult because land-parcel owner information in not publicly available in Canada, which meant I had no way of randomly selecting landowners for inclusion in the study. In the 2005 case study I traveled to Pelee Island, where the same Lake Erie Water Snake that is found on Middle Bass Island lives (see Olive 2014). I immediately met with the mayor of the island and used snowball sampling to interview landowners with shoreline property on this small island that has about 150 year-around residents. In total I completed 18 landowner interviews. In the 2015 Ontario case study I worked with a plant ecologist who had surveyed land in the southwestern part of the province. In the summer of 2014 the ecologist had determined key land parcels for rare plants and worked with landowners to survey land. We approached the same landowners in 2015 and inquired about an interview regarding endangered species conservation. Of the 37 landowners in the 2014 plant project, 22 agreed to be interviewed, which is a response rate of $57 \%$.

\section{Interviews}

In the three U.S. cases and the second Ontario case, landowners were first contacted by mail. A brief letter introducing the project was mailed to each house in the sample population. A week later I called each possible subject and requested an interview. I traveled to the homes of landowners who agreed to be interviewed to conduct the interview. In a few cases landowners were away from their homes and agreed to fill out the survey by phone or mail, as mentioned above. All interviews that were conducted in person 
Table 2. Landowner attitudes toward conservation.

\begin{tabular}{|c|c|c|c|c|}
\hline Question & Location & Agree & Disagree & Don't Know \\
\hline \multirow{2}{*}{$\begin{array}{l}\text { Do you think that landowners have an obligation to protect endangered species } \\
\text { on their property? }\end{array}$} & USA & 72 & 14 & 14 \\
\hline & Ontario & 82 & 12 & 6 \\
\hline \multirow{2}{*}{$\begin{array}{l}\text { Do you agree that it is okay to set limits on private property rights for } \\
\text { protection of endangered species? }\end{array}$} & USA & 54 & 27 & 20 \\
\hline & Ontario & 75 & 18 & 7 \\
\hline \multirow{2}{*}{$\begin{array}{l}\text { Do you think it is unfair to expect landowners to bear the cost of protecting } \\
\text { endangered species on their property? }\end{array}$} & USA & 55 & 25 & 20 \\
\hline & Ontario & 70 & 30 & 0 \\
\hline
\end{tabular}

lasted between 30 and 60 minutes. The interviews followed a semistructured format with many open-ended questions. This format allowed for different themes to arise over the duration of the interviews. A digital recorder captured each interview, including phone interviews, so that verbatim transcription was possible.

The interview questions probed landowners' knowledge of existing public policy and endangered species as well as their attitudes to conservation broadly speaking. The main focus of the interviews revolved around attitudes toward private property and government regulation. Landowners were asked in-depth about their relationship to the public agency enforcing the ESA. Toward the end of the interviews landowners were asked about their willingness to comply with the ESA, as well as their thoughts on tradeoffs between property rights and the ESA. Despite the difference in species and location across cases, the 141 landowners were asked the same questions. All participants also filled out a one-page demographics questionnaire.

\section{Analysis}

Although landowner attitudes toward private property, government regulation, and conservation have been explored elsewhere (see Olive 2014), this paper emphasizes three specific interview questions that center on the issue of fairness in regard to protecting endangered species on private lands. These questions are presented in Table 2. The data were transcribed and coded for agree/disagree responses as presented below. The author conducted 129 of the interviews. In the case of Indiana, 11 interviews were coconducted with another person, and in the case of Southern Ontario, 18 interviews were conducted by a third person. Two research assistants transcribed 35 of the interviews, and the author transcribed 106 interviews. The author completed all the coding of landowner responses into yes/no, agree/disagree categories and 22 interviews were coded by a second person to assess intercoder reliability with $96 \%$ agreement.

The analysis presented here draws more heavily on the qualitative data in the form of quotations from landowner interviews. These quotations provide a rich and more detailed description of how landowners feel about fairness and conservation on their own land. Each interview was carefully read with attention to claims about fairness and justice. The author analyzed 119 of the interviews, and a coresearcher analyzed the 22 transcripts from Southern Ontario. The analysis took a deductive approach using environmental justice theory, whereby all landowner claims pertaining to fairness were categorized into 4 categories: distributive claims, procedural claims (including future generations and ecological justice claims), recognition claims, and "other" claims. Based on the literature, the initial guiding assumption was that the majority of justice claims would be distributive (in the form of economic compensation) and that fewer claims would be made about procedural justice and justiceas-recognition.

\section{RESULTS}

In terms of demographics, the participants across the five cases tended to be white, educated, conservative, older, and male. Overall, $59 \%$ of landowners interviewed were male, with the highest percentage in Southern Ontario (81\%) and the lowest percent in Utah (45\%). Most interviewees had lived on their land for at least a decade; the average length across cases was 17 years. Just under half of the landowners $(46 \%)$ were college educated, and a majority earned more than a hundred thousand dollars annual income $(66 \%)$. Of the 141 participants, just over half $(53 \%)$ were aged 65 years or older and $91 \%$ classified themselves as white/ Caucasian. Despite these common characteristics, there was diversity within and across the sample populations. Individuals from different political parties and socioeconomic categories participated in the study (see Olive 2014). In both countries rural landowners tend to be older, white, conservative, and male (Warren 2003, Rural Ontario Institute 2013), so the participants in this study are largely representative of the target population.

In terms of attitudes about conservation, landowners in both countries believe there is an obligation to protect endangered species found on their own private land. For more than half of landowners the response was basically "without question," as one Indiana landowner said. See Table 2 for a numerical summation of the qualitative results. The landowners who expressed hesitation around this obligation did so on the basis of the type of species. Namely, landowners did not feel obligated to protect something that could harm their person or family (including their pets) or harm their land, such as a bear in the former case and a beaver in the latter case. One Utah landowner's response was "it depends on what the species is. The wolves - they endanger people." However, by and large, the vast majority of interviewees said they feel responsible for all wildlife on their land. The next logical step is to examine how this obligation plays out under the law. Are landowners willing to be regulated or even shoulder costs associated with conservation?

The majority of landowners felt that limitations on property rights are appropriate for the conservation of endangered species. Here, limitations include building permits and other land use regulations like brush clearing or making changes to wetlands. Landowners seemed quite willing to accept temporary regulations for conservation so long as a species is in danger of extinction, so as to suggest that limitations on private property are not valid in the case of wildlife not in danger of extinction. Of those that were 
Table 3. Landowner responses regarding the fairness of the Endangered Species Act.

Landowner response statements that reflect attitudes about fairness and the idea of property taxes.

I think it all comes out in our taxes (Indiana 2005).

I think we pay taxes. And they should divvy that up if they think it is that important (Ohio 2008).

We pay enough in taxes already (Ontario 2010).

I think that [land] is mine and I am paying taxes on it (Utah 2008).

You should have the right to do with your land what you want because you paid for it, you pay your taxes. If you didn't pay taxes, that might be different (Ohio 2008).

Landowner response statements that reflect the unfairness of government regulation on private lands

That is part of what the US is about itself. The fact that we have the ability to own private property and no one
can basically tell you what to do with that property. And that is sorta, you know, one of those basic inalienable rights that we have (Indiana 2005).

I wouldn't want the government to come in and say "by the way, we are taking these 6 acres now." I would say wait a minute, that's not fair. We own the land (Ontario 2015).

The government is too big. They control our lives (Ohio 2008).

They have no right to tell me what I can or can't do on my property. It is not fair (Utah 2008).

I almost think it is wrong. I don't want anyone regulating what I do with the land (Indiana 2005).

Landowner response statements that reflect attitudes about society asking individuals to shoulder costs.

I would say it is not fair to put a total burden on landowners. Because the endangered species being around is benefiting the whole community together (Ohio 2008).

Why does it need to be protected on private land, that is the question (Utah 2008).

Ah, I don't think there should be undue burden on me just because we've got this piece of land here with the snake. We shouldn't be responsible for saving that. Um, because, we are all in it together (Ohio 2008).

I think a society should not burden that one individual for all of society's interests (Indiana 2005).

unwilling to accept regulation, it was not out of spite for endangered species, but because they felt that regulations are unnecessary or go too far. For example, one landowner said, "Some regulations are good, but some landowners know how to do things on their own" (Ontario 2015). This speaks to the theme explored below that landowners consider themselves capable stewards of the land such that limitations are not necessary, even for endangered species conservation.

When asked if it is unfair to expect landowners to bear the cost of protecting endangered species, the majority of landowners agreed it is unfair. Although there was a large difference here between Canadian and U.S. landowners, note that $20 \%$ of U.S. landowners answered "don't know." The interview directly asked for landowners to expand upon their opinions. Table 3 explores the more qualitative aspect of the interviews and provides the reasoning behind the attitudes depicted in Table 2 . The main reasons landowners felt it is unfair concern three related points of contention: (1) taxes, (2) private property norms, and, (3) societal benefits provided by individuals. Table 3 organizes landowner responses around these three categories. In addition, to demonstrate that similar attitudes prevailed across the five case studies, quotations were pulled from different case studies. These attitudes in Table 3 (and Table 4), as expressed by landowners, provide a representative summation of attitudes in the overall study.

First, landowners believe that what they already pay in taxes should cover the necessary costs of protecting endangered species and they should not be asked for more money on top of those taxes. Indeed, anything more than that was unfair in their opinion. This was closely related to the other two issues. Landowners are okay with paying taxes so long as government leaves them alone and allows them to use their property as the landowners see fit. As Table 3 depicts, landowners in all locations associate strongly with their property and feel it is unfair for the government to dictate land management decisions. One confounding factor was that regulation of land is especially unfair when it is done in the name of society. That is to say, landowners felt they were being asked to shoulder a burden that belongs to all Americans and Canadians. In their eyes, it would be fairer for society to share the burden with them, or at least properly recognize landowners as stewards, as discussed below. 
Table 4. Landowner statements as environmental justice claims $(\mathrm{N}=691)$.

Landowner statements about distributive justice (as economic compensation) $\mathrm{N}=325$

I think the government, if they choose to value the rights of the endangered species over the landowner's rights, they should be required to compensate that landowner (Utah 2008).

Well, if they aren't going to give them the right to use their land then they should reimburse them (Indiana 2005).

If they [government] want protection [for endangered species on my land]—pay me (Ohio 2008).

If you don't want me to cut them down then I should be compensated (Indiana 2005).

I think education would go a long way. But so would incentives. Like some of the programs we have (Ontario 2015).

Landowner statements about procedural justice

$\mathrm{N}=233$

I will never allow government to dictate to me what I am going to do on my property ... they made that law without any of consultation or anything else like that (Ontario 2015).

They never consult the people they should. A lot of times when these decisions are handed down, it's like they never asked us (Ontario 2015).

Landowners went and they spoke and they presented papers and in my opinion they ignored them (Utah 2008).

Without me being consulted, for ... for a process to come through and say we have determined that you can't do this, no. But for a process to come through and say "you know what, we want to meet with the landowners and talk to you and say that 'this what we would like to propose and what do you think?'” ... to really be involved in that process, then I could accept that (Ohio 2008).

Just let me know a little more about what they are trying to do and maybe suggestions about what I maybe should try and plant if I have a chance to (Ohio 2008).

Landowner statements about justice-as-recognition

$\mathrm{N}=129$

I believe I am a responsible manager. I wouldn't need them [government] so I wouldn't tell them [I have an endangered species on my land] (Ontario 2008).

If I wanted to kill all the snakes, no one is going know. It really comes down to personal choice. But I have a lot of snakes on my land. So, I must be doing something right. We should get awards for the most snakes on our land. They [snakes] don't go places where they are killed all the time (Ohio 2008).

After being a little bullied here and feeling like I was treated as if I had no brains, I joined the Ontario landowners [sic] association (Ontario 2015).

We are just stewards. This land has been around for millions of years and I am here for a short time. I have never owned a piece of property that wasn't a better piece of property when I got rid of it than when I got it. That is what people don't recognize (Indiana 2005).

If you have good laws then a good citizen will obey those laws. And we are good citizens (Utah 2008).

Outside of these direct responses regarding the unfairness of shouldering costs associated with endangered species conservation (Table 3), landowner interviews were full of other references to fairness. In fact, numerous claims about each type of environmental justice, i.e., distributive, procedural, recognition, and other, surfaced during the interviews. In the 141 interviews, landowners made 691 claims about justice. These includes the direct responses to the three questions presented in Table 2, which in some cases resulted in only a yes/no statement without further elaboration by the landowner. However, some landowners spoke at length about fairness. In these cases each claim was counted as a single occurrence. Of the 691 claims, the majority were distributive claims: 325 claims compared with 233 claims about procedural fairness and 129 claims about recognition. The interview asked a specific question about distributive justice but no specific question about procedural justice or justice-as-recognition. Thus, we would expect a minimum of 141 distributive justice claims but no minimum for the other categories. Indeed, not all landowners made claims about procedural justice or justice-as-recognition.

The numbers do not add up to 691 because some claims were categorized into more than one type of claim. For example, a 
landowner could claim that he/she should be included in a decision process (procedural) because he/she is a good steward of the environment (recognition). The landowner wants to be recognized as a steward and included in decision making as a result. In total there were 16 claims that could be coded into more than one category. There were also 20 "other" claims that did not fit into one of the three environmental justice categories. These claims included blanket statements of "it is not fair" or "I don't think that is right" without further elaboration as to exactly what is unfair. There were also two individuals who claimed that the law is unfair because a neighbor is not penalized for violating the law. This could be a procedural justice claim but it was not clear from the landowner's statement, so these claims were coded as other. Table 4 provides five representative statements made by landowners across the cases. These statements are intended to demonstrate the breadth and scope of landowner conceptions of fairness.

As Table 4 illustrates, the distributive justice claims are straightforward. The landowner believes he/she is giving up something or doing something for conservation and should be compensated in return. For each landowner, the basic concern is a burden that is not being fairly distributed. In the first two example statements, the landowners are giving up the right to use the land in specific ways. These landowners want the public to financially compensate them for the loss of their property rights. In the third and fourth examples, the landowners are actively protecting the species through land management practices, such as not harvesting trees that serve as habitat, and ultimately believe that compensation should be provided for their service. In the last example, the landowner is replying to the last question asked during the interview, which was "What is the best way the government could help you protect endangered species on your land?" This landowner answered education and incentives.

The procedural justice claims in Table 4 display the animosity toward government felt by many landowners. The first three example statements deal with lack of consultation. Landowners in all case study locations felt left out of the process because no one told them about the species or the law. Of the 141 interviews, only a little fewer than a third of all landowners could explain how the law works in relation to their own land. Indeed, one of the most surprising finding in these cases is the lack of awareness and the lack of outreach by the government to individuals who own habitat for endangered species. Statement five in this category speaks to the need for information to meaningfully participate in protection and recovery. More specifically, as depicted in Table 4, landowners want to be included in conservation policy and the decisions that impact their land. Also, procedural justice must also be genuine participation and not "token inclusion." As the fourth sample statement suggests, even when landowners do participate, they can be ignored by government.

Finally, the justice-as-recognition statements indicate that landowners want the government and society to recognize rural landowners as stewards of the country. The interviews conducted in this study were all in small communities and rural locations. Some landowners had lived on their property all their lives and felt a close connection to the land and to the rural way of life. As Table 4 illustrates, landowners see themselves as "responsible managers," "stewards," and "good citizens." The second statement in this category suggests the idea of giving landowners awards for stewardship and conservation. It was not uncommon to hear this from landowners. In fact, in the 2015 Ontario case one older landowner remembered a plaque he had been given by a conservation agency for good stewardship more than 30 years earlier (in 1987). The landowner had kept the certificate and was eager to show it off. It meant a great deal to him that his stewardship efforts had been formally recognized. This is in stark contrast to the third example statement, where the landowner felt she was bullied by government and treated like she did not know anything about her land or how to take care of it. Although this category had the fewest statements overall, there were a lot of landowners who genuinely wanted recognition from society. Their attitudes went beyond distributive justice claims and procedural justice claims. It was not about being compensated and included, but acknowledged as stewards.

\section{DISCUSSION}

Although landowners do feel obligated to protect endangered species and are open to the idea of limiting property rights for conservation purposes, they are by and large against the idea of individual landowners bearing the cost of endangered species conservation. The reason is because they deem it unfair. Landowners feel they already pay enough in taxes to cover conservation costs and, moreover, that government regulation of private land is unfair, and so is society's expectation that a public good be the responsibility of private landowners. The U.S. and Ontario ESAs both expect landowners to bear costs associated with conservation, so the fact landowners perceive this as unfair is problematic. In the long run, this could severely comprise landowners" "willingness to act in favor of the environment" (Reese and Jacob 2015:88) as demonstrated in environmental justice scholarship.

Although the government response to unfairness concerns has been to increase compensation and create new tax incentive programs, this is not enough to appease landowners. This study demonstrates that greater attention must be given to other forms of fairness that are less documented in conservation literature, namely, procedural justice and justice-as-recognition. The 141 interviews illustrate that landowners are frustrated and alienated. The implication is that the United States and Ontario need to amend their ESAs to include landowners in protection and recovery decisions, and to recognize landowners as stewards and local experts. From a policy standpoint, what would this look like? This is hard to pinpoint, especially because landowners would need to be included in decisions about procedural justice and justice-and-recognition. However, a brief sketch of how the government could begin to address environmental justice is warranted here.

Procedural justice is not always straightforward. Landowners cannot be included in every aspect of conservation, especially when they lack the scientific or economic training to make sound decisions. This is not necessarily the fault of individual citizens because conservation decision makers should strive to include landowners and facilitate learning whenever possible. This is especially true when policy will impact day-to-day land management decisions. In these cases, inclusion, information exchange, and consultation with landowners would go a long way toward increasing policy acceptance and compliance. This may 
take the form of small group discussions or door-to-door discussions with landowners when a species is being listed or new habitat requirements are added to a recovery plan. In all 141 interviews, landowners wanted to know more about why the species is endangered and what the species needs to recover. Landowners want to be of help because they are eager for recovery to occur so that land restrictions will be removed. The situation should be a win-win-win for government, landowners, and endangered species. Right now, landowners do not understand the law, the process of the ESA, or how to protect and recover the species that cohabits their land. If the government is going to list a species on the ESA, it must inform landowners. In addition, this must be something beyond opening up a web portal for public input, as done under the ESA in both countries (see Ontario Ministry of Natural Resources and Forestry 2012 and the Office of the Federal Register 2016). Small group meetings and doorto-door consultations during the listing process will not be easy or inexpensive. However, they will increase landowners' judicial appraisal of the ESA and could lead to more voluntary compliance.

This paper has been rather silent on other moral categories in the stakeholder framework. The role of future generations, global citizens, and nature (the species themselves) requires further exploration and analysis. The focus here is on landowner participation in the process of making and implementing conservation policy. As the interviews reveal, landowners feel excluded or sometimes even bullied in ESA politics. The extent to which the rights of the endangered species should be considered in the process is not analyzed here. Similarly, the ways that biodiversity loss may impact future generations or people living in other countries are also not analyzed here. Procedural justice could require this degree of inclusion. Future research into environmental justice in endangered species conservation should explore these topics in detail.

Addressing justice-as-recognition will require that the government and communities recognize stewardship efforts made by landowners. Some interviewees spoke at great length about their willingness to care for land. These statements came from a place of love and pride. Many landowners felt that they are good stewards who should be rewarded and not punished for having endangered species on their land. The reward does not need to be financial; indeed, compensation is not what these landowners crave. Instead, recognition can be as simple as printing certificates, making plaques/trophies, or making signs landowners can post on their property. Although this type of recognition might not work for all landowners, it could work for some. In addition, it would be an inexpensive and positive way to highlight stewardship as well as advertise it. Moreover, it should be noted that recognition programs do not have to be organized or implemented by the government, but conservation agencies could immediately fill this void.

Additional research on justice-as-recognition is warranted. The literature on environmental justice is rich. The distribution of benefits and burdens has been explored in great detail with numerous case studies. This is true even inside conservation literature, because we know the importance of landowner incentives and compensation schemes (see Farrier 1995, Brook et al. 2003, Kreuter et al. 2006, Muradian et al. 2013). However, we know much less about the perceived fairness of conservation policy (Olive 2014, Pascual et al. 2014) and even less about the importance of landowner recognition. This paper links conservation with recognition. In the landowner interviews 129 claims were made about culture, lifestyle, and local knowledge that pertain directly to landowner conception of justice in conservation policy. The fact that landowners see themselves as capable stewards impacts their willingness to accept government regulation of private property.

More empirical research around policy design for justice-asrecognition is required. Ideally, more landowners would be consulted about how the government can better interact with property owners. Special attention needs to be paid to differing types of landowners: urban, agricultural (farmer and rancher), hobby farmers, and rural nonagricultural landowners. Acknowledgement of different types of justice might be necessary to encourage and embrace inclusion among and within different landowner groups. Recognition is deeply tied to identity, so how landowners self-identify may be of critical importance in properly recognizing their roles in stewardship. Landowners are not a homogenous group; therefore, environmental justice requires special attention to perceived fairness in different contexts. It has already been well documented that different compensation schemes are needed for different types of landowners (ranchers, large farmers, hobby farmers), so it should be anticipated that varied recognition schemas would also be necessary.

\section{CONCLUSION}

The U.S. and Ontario ESAs expect a lot from landowners. Endangered species need private landowners to engage in stewardship if recovery is ever going to be achieved. However, the design of the ESAs is such that private landowners feel penalized for having an endangered species on their property. The law prohibits not only outright killing of endangered species, but also habitat modification. This can severely restrict how a landowner uses his or her own property. This paper has argued that landowners in the U.S. and Ontario consider the ESAs to be unfair.

The feeling of unfairness stems in part from claims about distributive justice. Landowners feel that they already pay taxes so the government should not mandate land management practices and society should not expect individual sacrifice for a public good like endangered species. Thus, some landowners want compensation if there are costs beyond what is paid in taxes. Policy makers in the United States and Ontario have already focused a great deal on distributive justice in ESA politics. Both laws have numerous policies that seek to compensate or otherwise incentivize landowner cooperation with endangered species protection and recovery. However, as the interviews in this study reveal, landowners still feel the law is unfair and have grievances that extend beyond distributive justice claims. Although fewer claims about procedural justice and justice-as-recognition were made by landowners, this is largely a result of the interview structure itself. Each landowner was specifically asked about distribution but not other justice categories. Thus, the fact that other, unprompted, fairness claims were made about procedural justice and justice-as-recognition highlights the importance of these under-researched areas of conservation policy. 
Because land is more than just habitat for people and wildlife, economic compensation schemas alone will not be enough to address the burden that land use restrictions place on individual landowners. Instead, the governments must increase the transparency of decision making and open avenues for landowner participation in these decisions. Moreover, landowners also need to be nonfinancially recognized for their stewardship activities. Following a 1996 survey of Ontario landowners, Petersen made the claim that landowners "are tired of people telling them what to do" and encouraged the Ontario government to take a different approach. He said "treat them with respect and they will do the right thing" (Petersen 1996:12). This is the underlying principle of justice-as-recognition and echoes what numerous landowners in the U.S. and Ontario said during their interviews.

\section{Responses to this article can be read online at:} http://www.ecologyandsociety.org/issues/responses. $\mathrm{php} / 8627$

\section{Acknowledgments:}

I would like to acknowledge the financial support provided for the case study research from Purdue University, the University of Michigan-Dearborn, and the University of Toronto Mississauga. I would like to thank Dr. Jenny McCune for her contributions to the 2015 Ontario case study.

\section{LITERATURE CITED}

Aitken, M. 2010. Wind power and community benefits: challenges and opportunities. Energy Policy 38:6066-6075. http://dx.doi. org/10.1016/j.enpol.2010.05.062

Bean, M. J. 1998. The Endangered Species Act and private land: four lessons learned from the past quarter century. Environmental Law Reporter 28(12):10701-10710.

Brook, A., M. Zint, and R. De Young. 2003. Landowners' responses to an Endangered Species Act listing and implications for encouraging conservation. Conservation Biology 17 (6):1638-1649. http://dx.doi.org/10.1111/j.1523-1739.2003.00258. $\underline{\mathrm{X}}$

Cantzler, J. M., and M. Huynh. 2016. Native American environnemental justice as decolonization. American Behavioral Scientist 60(2):203-223. http://dx.doi.org/10.1177/0002764215607578

Clayton, S. 2000. New ways of thinking about environmentalism: models of justice in the environmental debate. Journal of Social Issues 56(3):459-474. http://dx.doi.org/10.1111/0022-4537.00178

Cropanzano, R., and M. L. Ambrose. 2001. Procedural and distributive justice are more similar than you think: a monistic perspective and research agenda. Pages 119-151 in J. Greenberg and R. Cropanzano, editors. Advances in organizational justice. Stanford University Press, Stanford, California, USA.

Cowell, R., G. Bristow, and M. Munday. 2012. Wind energy and justice for disadvantaged communities. Joseph Rowntree Foundation, York, UK.

Dempsey, J., P. Dearden, and J. G. Nelson. 2002. Stewardship: expanding ecosystem protection. Pages 379-397 in P. Dearden and
R. Rollins, editors. Parks and protected areas in Canada: planning and management. Oxford University Press, Toronto, Ontario, Canada.

Doremus, H. 2003. A policy portfolio approach to biodiversity protection on private lands. Environmental Science \& Policy 6:217-232. http://dx.doi.org/10.1016/S1462-9011(03)00036-4

Farrier, D. 1995. Conserving biodiversity on private land: incentives for management of compensation for lost expectations? Harvard Environmental Law Review 19:303.

Fehr, E., and A. Falk. 2002. Psychological foundations of incentives. European Economic Review 46:687-672. http://dx.doi. org/10.1016/S0014-2921(01)00208-2

Fletcher, T. H. 2003. From Love Canal to environmental justice: the politics of hazardous waste on the Canada-U.S. border. University of Toronto Press, Toronto, Ontario, Canada.

Ingram, H., J. M. Whitely, and R. W. Perry. 2008. The importance of equity and the limits of efficiency in water resources. Pages 1-32 in J. M. Whiteley, H. Ingram, and R. W. Perry, editors. Water, place, and equity. MIT Press, Cambridge, Massachusetts, USA. http://dx.doi.org/10.7551/mitpress/9780262232715.003.0001

Kals, E., and Y. Russell. 2001. Individual conceptions of justice and their potential for explaining proenvironmental decision making. Social Justice Research 14:367-385. http://dx.doi. org/10.1023/A:1014698528132

Kittredge, D. B., A. G. Short Gianotti, L. R. Hutyra, D. R. Foster, and J. M. Getson. 2015. Landowner conservation awareness across rural-to-urban gradients in Massachusetts. Biological Conservation 184:79-89. http://dx.doi.org/10.1016/j.biocon.2015.01.001

Knight, M. 2006. Factors influences landowner support for stewardship in the Carolinian zone. Thesis. University of Waterloo, Waterloo, Ontario, Canada.

Kreuter, U., M. V. Nair, D. Jackson-Smith, J. R. Conner, and J. E. Johnston. 2006. Property rights orientations and rangeland management objectives: Texas, Utah, and Colorado. Rangeland Ecology \& Management 59(6):632-639. http://dx.doi. org/10.2111/05-173R1.1

Levi, M. 1997. Consent, dissent, and patriotism. Cambridge University Press, New York, New York, USA. http://dx.doi. org/10.1017/cbo9780511609336

Martin A., A. Akol, and J. Phillips. 2013. Just conservation? On the fairness of sharing benefits. Pages 69-91 in T. Sikor, editor. The justices and injustices of ecosystem services. Earthscan, London, UK.

May, P. J. 2004. Compliance motivations: affirmative and negative bases. Law \& Society Review 38(1):41-68. http://dx.doi. org/10.1111/j.0023-9216.2004.03801002.x

Milburn, L.-A. S., R. Brown, and S. J. Mulley. 2010. ' ‘. Silver in the stars and gold in the morning sun': non-farm rural landowners' motivations for rural living and attachment to their land. Landscape Research 35(1):27-46. http://dx.doi. org/10.1080/01426390903407152

Miller, N. 2007. Legislative Assembly of Ontario. Debates and proceedings. Session 38:2. Edited Hansard. Number L175A. Wednesday May 16. 
Muller, M. M., and S. Clayton. 2013. Introduction to “environmental justice." Social Justice Research 26(3):227-230. http://dx.doi.org/10.1007/s11211-013-0194-y

Muradian, R., M. Arsel, L. Pellegrini, F. Adaman, B. Aguilar, B. Agarwal, E. Corbera, D. Ezzine de Blas, J. Farley, G. Froger, et al. 2013. Payments for ecosystem services and the fatal attraction of win-win solutions. Conservation Letters 6:274-279. http://dx. doi.org/10.1111/j.1755-263X.2012.00309.X

Office of the Federal Register. 2016. Endangered \& threatened species. Federal Register: The Daily Journal of the United States Government. Office of the Federal Register, Washington, D.C., USA. [online] URL: https://www.federalregister.gov/endangeredthreatened-species

Olive, A. 2014. Land, stewardship, and legitimacy. University of Toronto Press, Toronto, Ontario, Canada.

Olive, A., and L. Raymond. 2010. Reconciling norm conflict in endangered species conservation on private land. Natural Resources Journal. 50(2):431-454.

Ontario Biodiversity Council. 2010. State of Ontario's biodiversity 2010 - highlights report. A report of the Ontario Biodiversity Council, Peterborough, Ontario, Canada. http://viewer.zmags. com/publication/04bd7b67\#/04bd7b67/2

Ontario Ministry of Natural Resources and Forestry. 2012. Grants for protecting species at risk. Ontario Ministry of Natural Resources and Forestry, Peterborough, Ontario, Canada. [online] URL: https://www.ontario.ca/page/grants-protecting-species-risk

Ontario Ministry of Natural Resources and Forestry. 2015. How to comment on protecting species at risk. Ontario Ministry of Natural Resources and Forestry, Peterborough, Ontario, Canada. [online] URL: http://www.ontario.ca/page/how-comment-protectingspecies-risk

Ottinger, G., T. J. Hargrave, and E. Hopson. 2014. Procedural justice in wind facility siting: recommendations for state-led siting processes. Energy Policy 65:662-669. http://dx.doi.org/10.1016/j. enpol.2013.09.066

Parkhurst, G. M., and J. F. Shogren. 2003. Evaluating incentive mechanisms for conserving habitat. Natural Resources Journal 43:1093-1149.

Pascual, U., R. Muradian, L. C. Rodriquez, and A. Duraiappah. 2010. Exploring the links between equity and efficiency in payments for environmental services: a conceptual approach. Ecological Economics 69:1237-1244. http://dx.doi.org/10.1016/j. ecolecon.2009.11.004

Pascual, U., J. Phelps, E. Garmendia, K. Brown, E. Corbera, A. Martin, E. Gomez-Baggethum, and R. Muradian. 2014. Social equity matters in payments for ecosystem services. BioScience 64 (11):1027-1036. http://dx.doi.org/10.1093/biosci/biu146

Petersen, J. 1996. Carolinian Canada landowner survey report. Carolinian Canada, Ministry of Natural Resources, Peterborough, Ontario, Canada.

Peterson, T. R., and C. Choat Horton. 1995. Rooted in the soil: how understanding the perspectives of landowners can enhance the management of environmental disputes. Quarterly Journal of Speech 81:139-166. http://dx.doi.org/10.1080/00335639509384106
Raymond, L., and A. Olive. 2008. Landowner beliefs regarding biodiversity protection on private property: an Indiana case study. Society \& Natural Resources 21(6):483-497. http://dx.doi. org/10.1080/08941920801905203

Reese, G., and L. Jacob. 2015. Principles of environmental justice and pro-environmental action: a two-step process model of moral anger and responsibility to act. Environmental Science \& Policy 51:88-94. http://dx.doi.org/10.1016/j.envsci.2015.03.011

Rural Ontario Institute. 2013. Growth in number of seniors. Rural Ontario Institute, Guelph, Ontario, Canada. [online] URL: http://www.ruralontarioinstitute.ca/uploads/userfiles/files/Focus $\%$ 208\%20Growth $\% 20 \mathrm{in} \% 20$ number $\% 20$ of $\% 20$ seniors.pdf

Schlosberg, D. 2004. Reconceiving environmental justice: global movements and political theories. Environmental Politics 13 (3):517-540. http://dx.doi.org/10.1080/0964401042000229025

Schlosber, D., and D. Carruthers. 2010. Indigenous struggles, environmental justice, and community capabilities. Global Environmental Politics 10(4):12-35. http://dx.doi.org/10.1162/ GLEP a 00029

Sikor, T. 2013. Introduction: linking ecosystem services with environmental justice. Pages 1-18 in T. Sikor, editor. The justices and injustices of ecosystem services. Earthscan, London, UK.

Sikor, T., A. Martin, J. Fisher, and J. He. 2014. Toward an empirical analysis of justice in ecosystem governance. Conservation Letters 7(6):524-532. http://dx.doi.org/10.1111/ conl.12142

Sorice, M. G., J. R. Conner, U. P. Kreuter, and R. N. Wilkins. 2012. Centrality of the ranching lifestyle and attitudes toward a voluntary incentive program to protect endangered species. Rangeland Ecology \& Management 65(2):144-152. http://dx.doi. org/10.2111/rem-d-10-00144.1

Stern, S. 2006. Encouraging conservation on private lands: a behavioral analysis of financial incentives. Arizona Law Review 48:541-592.

Stone, D. 1990. Policy paradox: the art of political decisionmaking. First edition. Norton and Company, New York, New York, USA.

Tyler, T. 1990. Why people obey the law. Yale University Press, New Haven, Connecticut, USA.

Turner, N. J., R. Gregory, C. Brooks, L. Failing, and T. Satterfield. 2008. From invisibility to transparency: identifying the implications. Ecology and Society 13(2):7. [online] URL: $\underline{\text { http:// }}$ www.ecologyandsociety.org/vol13/iss $2 / \operatorname{art} 7 /$

U.S. Fish and Wildlife Service. 2015. Endangered species: for landowners. U.S. Fish and Wildlife Service, Falls Church, Virginia, USA. [online] URL: http://www.fws.gov/endangered/

Warren, S. T. 2003. One step further: women's access to and control over farm and forest resources in the U.S. South. Southern Rural Sociology 19(2):94-113.

Wright N. D., K. Hodgson, S. M. Fleming, M. Symmonds, M. Guitart-Masip, and R. J. Dolan. 2012. Human responses to unfairness with primary rewards and their biological limits. Scientific Reports 2(593). http://dx.doi.org/10.1038/srep00593 